\title{
Gold-containing metal nanoparticles for catalytic hydrogen generation from liquid chemical hydrides
}

\author{
Xinchun Yang a,b, Qiang Xu a,b,* \\ a National Institute of Advanced Industrial Science and Technology (AIST), Ikeda, Osaka 563-8577, Japan \\ ${ }^{\mathrm{b}}$ Graduate School of Engineering, Kobe University, Nada Ku, Kobe, Hyogo 657-8501, Japan
}

\section{A R T I C L E I N F}

\section{Article history:}

Received 12 April 2016

Accepted 10 May 2016

Published 5 October 2016

\section{Keywords:}

Gold catalysts

Hydrogen generation

Formic acid

Ammonia borane

Heterogeneous catalysis

\begin{abstract}
A B S T R A C T
Liquid chemical hydrides, which store hydrogen in the form of chemical bonds, are considered one of the most promising classes of hydrogen storage materials. Their application depends heavily on the development of efficient catalytic systems. Gold-containing metal nanoparticles have exhibited excellent catalytic performance for hydrogen generation from liquid chemical hydrides. The present mini-review focuses on recent developments in hydrogen generation from liquid chemical hydrides using gold-nanoparticle and gold-containing heterometallic nanoparticle catalysts.
\end{abstract}

(C) 2016, Dalian Institute of Chemical Physics, Chinese Academy of Sciences. Published by Elsevier B.V. All rights reserved.

\section{Introduction}

Hydrogen is considered a clean, effective and renewable energy carrier for a sustainable future [1-3]. In particular, hydrogen fuel cells can efficiently generate electricity to power vehicles and other devices without any emission of regulated gas pollutants [4-6]. Over the past decades, several advanced storage systems, such as cryogenic liquid cylinders, high-pressure gas cylinders and porous materials including zeolites, carbons and metal-organic frameworks have been developed for hydrogen storage [7-10]. However, these systems still face practical challenges in that they are not able to meet the demands required for practical applications because of their technological limits in safety (high pressure, low temperature) and density (low volumetric/gravimetric hydrogen densities).

Recently, concepts for hydrogen production from liquid chemical hydrides, such as formic acid and ammonia borane, have gained considerable interest [11-13]. Since hydrogen is stored in a safe and stable manner in the form of chemical bonds, liquid chemical hydrides possessing high hydrogen contents are easy to handle. Additionally, as liquid chemical hydrides have similar characteristics to common fuels, they can be effectively employed into already existing infrastructures. A number of homogeneous and heterogeneous catalysts with very high catalytic activities have been investigated for hydrogen generation from liquid chemical hydrides [14-18].

Since the report on the catalytic oxidation of CO using gold nanoclusters by Haruta in the 1980s, gold catalysts have attracted a wealth of interdependent research [19-22]. Hitherto, significant progress of gold catalysis has been achieved for various reactions [23-26]. Not only monometallic gold catalysts but also gold-containing heterometallic nanoparticles (NPs) have shown superior catalytic performance for various

\footnotetext{
* Corresponding author. Tel: +81-72-7519562; Fax: +81-72-7519628; E-mail: q.xu@aist.go.jp

This work was supported by Ministry of Economy, Trade and Industry (METI), National Institute of Advanced Industrial Science Technology (AIST) and Kobe University.

DOI: 10.1016/S1872-2067(16)62547-0 | http://www.sciencedirect.com/science/journal/18722067 | Chin. J. Catal., Vol. 37, No. 10, October 2016
} 
reactions, involving catalytic hydrogen generation from liquid chemical hydrides. In this mini-review, we detail the recent advances in the utilization of gold NPs and gold-containing metal alloy and core-shell NPs as catalysts for hydrogen generation from liquid chemical hydrides, formic acid ( $\mathrm{HCOOH})$ and ammonia borane $\left(\mathrm{NH}_{3} \mathrm{BH}_{3}\right)$.

\section{Formic acid dehydrogenation}

Formic acid, as a promising hydrogen carrier, has several remarkable features to include: (1) nontoxicity with a high hydrogen content (4.4 wt\%), (2) high stability as a liquid at room temperature, and (3) the availability via various synthesis routes, e.g., biomass process, $\mathrm{CO}_{2}$ hydrogenation or methyl formate hydrolysis [27-30]. Typically, suitable catalysts are used to facilitate formic acid decomposition via dehydrogenation $\left(\mathrm{HCOOH} \rightarrow \mathrm{H}_{2}+\mathrm{CO}_{2}, \Delta G_{298 \mathrm{k}}=-48.8 \mathrm{~kJ} \cdot \mathrm{mol}^{-1}\right)$ for practical applications, rather than dehydration $\left(\mathrm{HCOOH} \rightarrow \mathrm{H}_{2} \mathrm{O}+\mathrm{CO}\right.$, $\Delta G_{298 \mathrm{k}}=-28.5 \mathrm{~kJ} \cdot \mathrm{mol}^{-1}$ ), which produces the $\mathrm{CO}$ impurity that is toxic to fuel cell catalysts [31,32].

Monometallic gold NPs, as efficient heterogeneous catalysts for formic acid dehydrogenation, have received tremendous attention, owing to their high activity, ease of separation and efficient recycling [33]. We have reported amine-functionalized silica nanospheres encapsulated gold NPs as catalysts for hydrogen generation from formic acid [34]. Unlike gold NPs encapsulated in silica nanospheres in the absence of functional amine groups, the gold NPs encapsulated in the amine-functionalized counterparts show very high activity for the dehydrogenation of formic acid, releasing CO-free hydrogen with fast kinetics at $90{ }^{\circ} \mathrm{C}$ (Fig. 1). The strong metal-molecular support interaction (SMMSI) between the encapsulated gold NPs and the amine-functionalized $\mathrm{SiO}_{2}$ spheres was suggested as the reason for the high catalytic activity. It has been demonstrated that the acid-tolerant $\mathrm{ZrO}_{2}$-supported gold nanocluster $(\sim 1.8 \mathrm{~nm})$ catalysts can facilitate the liberation of CO-free hydrogen from formic acid-amine mixtures with a high turnover frequency (TOF) of $1590 \mathrm{~h}^{-1}$ at $50{ }^{\circ} \mathrm{C}$ under ambient conditions [35]. Most recently, Zhang and co-workers [36] developed

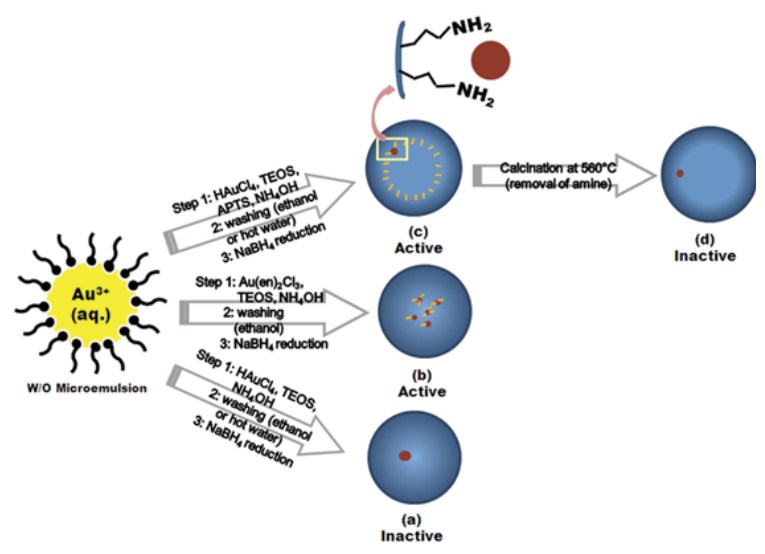

Fig. 1. Microemulsion-based syntheses of gold nanocatalysts encapsulated within hollow silica nanospheres of $\mathrm{Au} @ \mathrm{SiO}_{2}(\mathrm{a}), \mathrm{Au} @ \mathrm{SiO}_{2} \mathrm{EN}_{\text {(b), }}$ $\mathrm{Au} @ \mathrm{SiO}_{2} \mathrm{AP}$ (c), and Au@SiO${ }_{2} \mathrm{AP} \_\mathrm{C}$ (d). Reproduced from Ref. [34] with permission. Copyright Royal Society of Chemistry, 2012.
Schiff base-functionalized gold NPs for the catalytic dehydrogenation of high-concentration formic acid in the absence of additives. The reactions proceeded efficiently with a high TOF of $4368 \mathrm{~h}^{-1}$ in $10 \mathrm{~mol} \mathrm{~L}^{-1}$ formic acid solutions at $50{ }^{\circ} \mathrm{C}$. The enhanced catalytic feature was assigned to the $\mathrm{C}-\mathrm{H}$ activation between the protonated Schiff base and electronegative gold NPs at the interface.

Gold-containing metal alloy NPs have also been reported to be superior catalysts for dehydrogenation of formic acid. Xing and co-workers [37] used carbon supported AuPd NPs with an average particle size of $\sim 3.5 \mathrm{~nm}$ for the decomposition of formic acid, and achieved high activity, although a minor trace of CO was generated. The catalytic performance was further improved by introducing $\mathrm{CeO}_{2}$ as a promoter, and a maximum TOF of $832 \mathrm{~h}^{-1}$ was obtained at $102{ }^{\circ} \mathrm{C}$. Furthermore, Mullins and co-workers [38] confirmed that the bimetallic AuPd alloy NPs were excellent catalysts for formic acid dehydrogenation because of appropriate synergetic effects. Most recently, by using a $\mathrm{Mg}^{2+}$-assisted low temperature reduction approach, Chen and co-workers [39] have successfully immobilized small AuPd alloy NPs on carbon supports for hydrogen generation from formic acid, which achieved an initial TOF of $1120 \mathrm{~h}^{-1}$ at room temperature without $\mathrm{CO}$ emission.

Recently, various advanced functional materials have been explored as supports to further improve the catalytic performance of gold-containing metal alloy NPs. Porous metal-organic frameworks (MOFs) have proved to be unique hosts to encapsulate metal NPs with controlled particle sizes and distributions [40-42]. We have employed MIL-101, one of the representative MOFs, and its ethylenediamine-grafted counterpart to support AuPd alloy NPs, which were used as highly active catalysts for the complete conversion of formic acid. The synergistic effects between $\mathrm{Au}$ and Pd were observed in this bimetallic AuPd NP and a high tolerance with respect to CO poisoning was obtained [43]. This work also drew increased interest in MOF-immobilized NPs as catalysts for formic acid decomposition [44-46]. Graphene, a single-layer $s p^{2}$-hybridized carbon sheet, has recently been considered as a promising metal NP catalyst support because of its large surface area and excellent stability [47-50]. Yan and co-workers [51] have shown that the $\mathrm{N}$-doped reduced graphene oxide (rGO) can be used as an excellent support for immobilizing ultrafine AuPd-CeO $\mathrm{C}_{2}$ nanocrystals for formic acid dehydrogenation. They further prepared a bi-support consisting of ZIF-8 and rGO to immobilize AuPd-MnO ${ }_{x}$ NPs, which showed high catalytic activity in formic acid dehydrogenation with an initial TOF of $382.1 \mathrm{~h}^{-1}$ at $25^{\circ} \mathrm{C}$ in the absence of additives [52]. Very recently, we reported a highly active rGO-supported AuPd alloy nanoparticle catalyst synthesized using a non-noble metal sacrificial approach (NNMSA) for hydrogen production from formic acid [53]. As highly dispersed AuPd NPs were successfully immobilized on the rGO by the sacrifice of the co-precipitated $\mathrm{Co}_{3}\left(\mathrm{BO}_{3}\right)_{2}$, our catalysts exhibited the highest TOF of $4840 \mathrm{~h}^{-1}$ at $50{ }^{\circ} \mathrm{C}$ with no trace of $\mathrm{CO}$ emissions (Fig. 2).

Recently, considering the reduction of consumption of the noble metals, a trimetallic system consisting of Co, $\mathrm{Au}$ and $\mathrm{Pd}$ has been studied for the dehydrogenation of formic acid at 

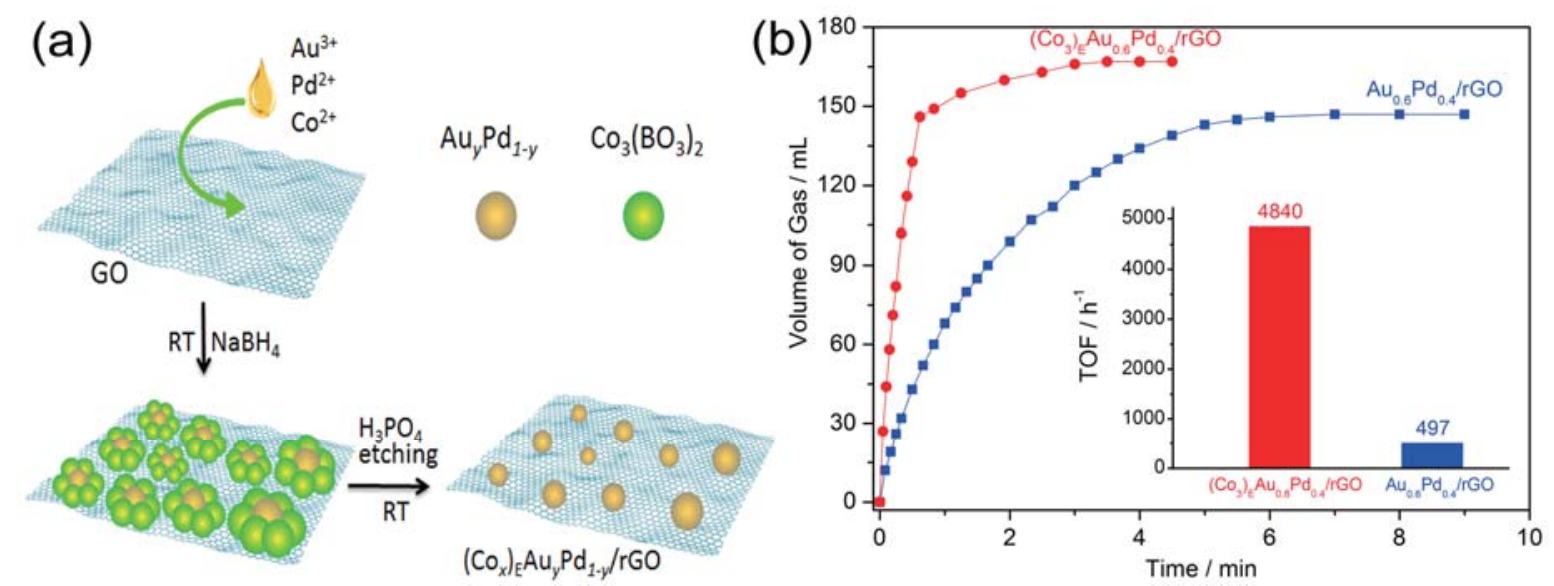

Fig. 2. (a) Schematic illustration of AuPd NP immobilization on reduced graphene oxide (rGO) via a non-noble metal sacrificial approach (NNMSA); (b Volume of the generated gas $\left(\mathrm{H}_{2}+\mathrm{CO}_{2}\right)$ versus time for the dehydrogenation of formic acid $(\mathrm{FA})$ over the $\left(\mathrm{Co}_{3}\right)_{\mathrm{E}} \mathrm{Au}_{0.6} \mathrm{Pd} \mathrm{Pd}_{0.4} / \mathrm{rGO}_{\mathrm{G}}$ and $\mathrm{Au}_{0.6} \mathrm{Pd}_{0.4} / \mathrm{rGO}$ catalysts (inset: the corresponding turnover frequency (TOF) values) ( $\left.n_{\mathrm{AuPd}} / n_{\mathrm{FA}}=0.02, n_{\mathrm{SF}} / n_{\mathrm{FA}}=2.5,50{ }^{\circ} \mathrm{C}\right)$. Reproduced from Ref. [53] with permission. Copyright Royal Society of Chemistry, 2016.

room temperature [54]. By introducing the non-noble metal Co, the resulting surface electronic state in the alloy structure changed, which enhances the catalytic properties of noble alloy metals. The system showed a TOF of $80 \mathrm{~h}^{-1}$ without the production of CO.

A core-shell structure may also improve the catalytic performance of gold-containing metal alloy NPs. Xing and co-workers [55] prepared core (PdAu)-shell ( $\mathrm{Au}) \mathrm{NPs}$, which exhibited significantly enhanced catalytic activity and stability than the monometallic Au and Pd NPs for the formic acid decomposition reaction.

\section{Ammonia borane hydrolysis}

Ammonia borane $\left(\mathrm{NH}_{3} \mathrm{BH}_{3}\right)$, as a potential alternative for hydrogen storage and supply, has drawn significant attention because of several advantages: (1) low molecular weight (30.9 $\mathrm{mg} \cdot \mathrm{L}^{-1}$ ) with high hydrogen content (19.6 wt\%), (2) high solubility and stability in water at room temperature, and (3) environmental nontoxicity $[11,12,56]$. Furthermore, the hydrogen stored in ammonia borane can be released using a suitable catalyst even at low temperatures through the desirable hydrolysis of ammonia borane according to the equations: $\mathrm{NH}_{3} \mathrm{BH}_{3}+2 \mathrm{H}_{2} \mathrm{O} \rightarrow \mathrm{NH}_{4} \mathrm{BO}_{2}+3 \mathrm{H}_{2}$. The hydrolysis of ammonia borane has been considered a safe and economical route for hydrogen production as it leads to controlled hydrogen release under mild reaction conditions with faster rates.

The current interest in heterogeneous catalysis for hydrogen generation from ammonia borane stems from our first report, which demonstrated that metal catalysts, such as Pt, Ru and Rh showed high catalytic activity toward hydrolytic dehydrogenation of ammonia borane $[57,58]$. Thereafter, significant progress has been made in the hydrolysis of ammonia borane under mild conditions [59-61], and several reviews have been published in this area $[11,12,56,62]$. Herein, we only focus on the use of gold-containing metal NPs in the catalytic hydrolysis of ammonia borane.

Through intensive efforts over the past decade, various monometallic noble metal NPs, such as $\mathrm{Rh}, \mathrm{Ru}$ and $\mathrm{Pt}$, and non-noble metal NPs such as Ni, Co and Fe have exhibited high catalytic activities toward hydrolytic dehydrogenation of ammonia borane [62-65], while monometallic gold NPs typically exhibit low catalytic performance in the hydrolysis of ammonia borane $[57,66]$. Recently, gold-containing metal alloy NP catalysts have attracted considerable interest, in which the synergistic effect between gold and additional metals may result in enhanced catalytic performance. Conversely, for practical applications, utilizing non-noble metals may significantly reduce the catalyst cost without hindering catalytic performance. In this context, our group has used silica nanospheres to support AuNi and AuCo NPs with diameters of 3-4 nm by in situ reduction in an aqueous solution of $\mathrm{NaBH}_{4} / \mathrm{NH}_{3} \mathrm{BH}_{3}$, which could efficiently catalyze the hydrolysis of ammonia borane $[67,68]$. Notably, these bimetallic AuNi and AuCo NPs have higher catalytic activities than their monometallic counterparts owing to a strong synergistic effect between $\mathrm{Au}$ and $\mathrm{Ni}$ (Co).

In addition to bimetallic alloys, gold-containing core-shell structures have also been developed to achieve high catalytic performance for the hydrolysis of ammonia borane. We have prepared a magnetically recyclable Au@Co core-shell NP catalyst by using a one-step seeding-growth route with ammonia borane as a suitable reducing agent [69]. The resultant Au@Co core-shell NPs showed excellent catalytic activity and stability for the hydrolysis of ammonia borane at room temperature. Similarly, magnetically recyclable $\mathrm{Au} / \mathrm{Co} / \mathrm{Fe}$ core-shell NPs with higher catalytic activity for ammonia borane hydrolysis have also been synthesized [70]. Recently, Cho et al. [71] reported octahedral Au@Pt core-shell NPs synthesized via a polyol method using poly(-diallyldimethylammonium chloride) (PDDA) as a capping agent. When Pt coverage on the Au NPs was optimized to a $\mathrm{Pt} / \mathrm{Au}$ ratio of 1 , the Au@Pt catalyst displayed the highest catalytic activity with an activation energy of $44.28 \mathrm{~kJ} \mathrm{~mol}^{-1}$.

The synergistic effects between metal nanoparticles and catalyst supports can be designed to control the aggregation and dispersion of metal NPs over the surface of the catalyst 

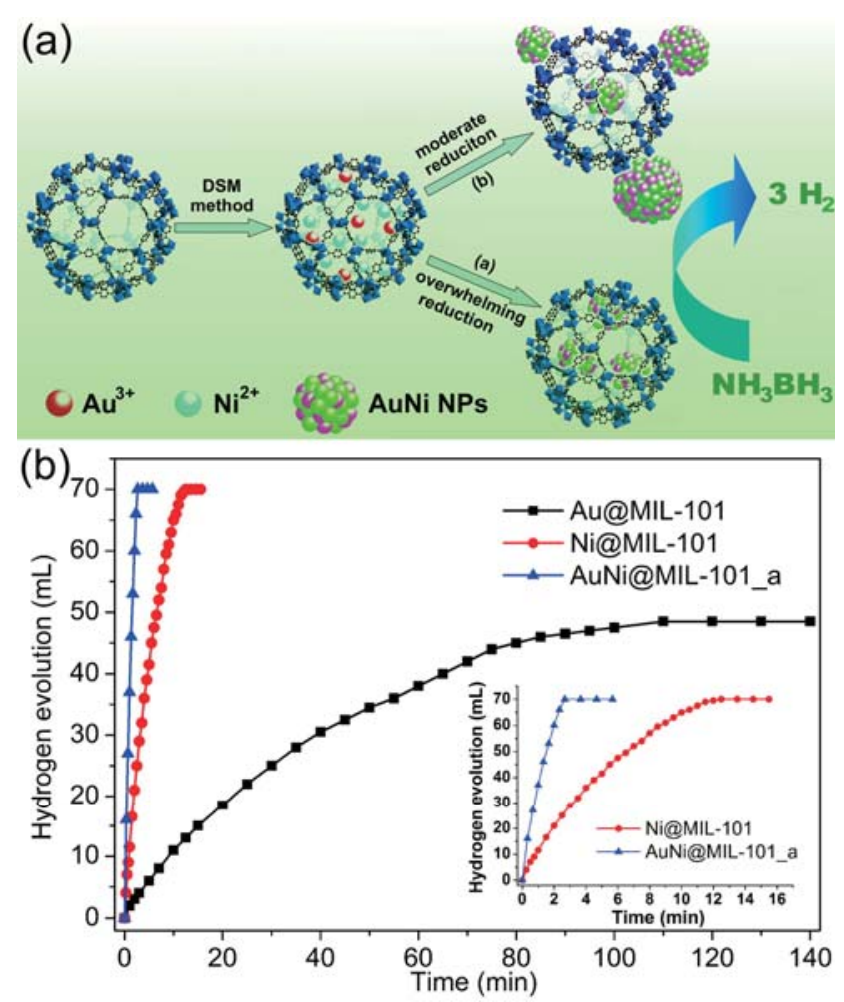

Fig. 3. (a) Schematic representation of AuNi NPs immobilization by the MIL-101 matrix using the double solvent method combined with a liquid-phase concentration-controlled reduction strategy; (b) Plots of time versus volume of hydrogen generated from ammonia borane hydrolysis at room temperature catalyzed by the Au@MIL-101, Ni@MIL-101, and AuNi@MIL-101_a catalysts. Reproduced from Ref. [73] with permission. Copyright American Chemical Society, 2013.

support, leading to improved catalytic activities. Carbon nitride (CN)-supported AuCo NPs prepared by a modified wet impregnation method were used for hydrogen production from the hydrolysis of ammonia borane [72]. Under mild conditions in the presence of photo irradiation,AuCo@CN displayed high activity for hydrogen generation with a TOF value of $2897 \mathrm{~h}^{-1}$ at room temperature. The synergetic effect between $\mathrm{Au}$ and Co and the Motty-Schottky effect at the metal-semiconductor interface were suggested to account for the high catalytic properties. Recently, we have successfully encapsulated ultrafine AuNi NPs in the pores of MOF MIL-101 using the double solvent method (DSM) in combination with a liquid-phase concentration-controlled reduction (CCR) strategy (Fig. 3) [73]. The obtained AuNi NPs exhibit excellent catalytic activity for hydrogen generation from ammonia borane hydrolysis, with a $\mathrm{Ni} / \mathrm{Au}$ ratio of 93:7, giving a TOF value of $66.2 \mathrm{~min}^{-1}$ at room temperature, comparable to the most active noble-metal $\mathrm{Pt}, \mathrm{Rh}$, and $\mathrm{Ru}$ NPs. Additionally, the same method was employed to prepare MIL-101 encapsulated AuCo NPs with an average size of 1.8 nm, which exhibited high activity and durability for the hydrolysis of ammonia borane at room temperature [74].

\section{Conclusions}

A number of gold and gold-containing metal NP catalysts with high selectivity and durability have been developed for hydrogen generation from liquid chemical hydrides in recent years, which show promise for future applications. Catalyst activity in this area has improved over the years and in continuing the trend there are encouraging signs that future catalysts will further improve activity, especially the non-noble metal/gold nanocomposite catalyst systems, in which the secondary non-noble metals play a significant role in enhancing catalytic performance, and to reduce catalyst cost. The outlook of commercializing chemical hydrides as hydrogen sources looks promising with gold-containing metal NP catalysts likely to make the breakthrough in near future.

\section{Acknowledgments}

The authors thank the editors for the kind invitation and METI, AIST and Kobe University for financial support. X. C. Yang is grateful to the China Scholarship Council (CSC) and Ministry of Education, Culture, Sports, Science and Technology-Japan (MEXT) for a PhD scholarship.

\section{References}

[1] H. Balat, E. Kirtay, Int. J. Hydrogen Energy, 2010, 35, 7416-7426.

[2] A. Boddien, B. Loges, F. Gärtner, C. Torborg, K. Fumino, H. Junge, R. Ludwig, M. Beller, J. Am. Chem. Soc., 2010, 132, 8924-8934.

[3] S. E. Hosseini, M. A. Wahid, Renew. Sustain. Energy Rev., 2016, 57, 850-866

[4] S. Ahmed, M. Krumpelt, Int. J. Hydrogen Energy, 2001, 26, 291-301.

[5] C. M. Pedersen, M. Escudero-Escribano, A. Velázquez-Palenzuela, L. H. Christensen, I. Chorkendorff, I. E. L. Stephens, Electrochim. Acta, 2015, 179, 647-657.

[6] W. Liu, C. J. Webb, E. M. Gray, Int. J. Hydrogen Energy, 2016, 41, 3485-3507.

[7] G. Li, H. Kobayashi, J. M. Taylor, R. Ikeda, Y. Kubota, K. Kato, M. Takata, T. Yamamoto, S. Toh, S. Matsumura , H. Kitagawa, Nat. Mater., 2014, 13, 802-806.

[8] L. Schlapbach, A. Zuttel, Nature, 2001, 414, 353-358.

[9] N. L. Rosi, J. Eckert, M. Eddaoudi, D. T. Vodak, J. Kim, M. O'Keeffe, O. M. Yaghi, Science, 2003, 300, 1127-1129.

[10] S. L. Li, Q. Xu, Energy Environ. Sci., 2013, 6, 1656-1683.

[11] M. Yadav, Q. Xu, Energy Environ. Sci., 2012, 5, 9698-9725.

[12] Q. L. Zhu, Q. Xu, Energy Environ. Sci., 2015, 8, 478-512.

[13] T. Umegaki, Q. Xu, Y. Kojima, Materials, 2015, 8, 4512-4534.

[14] Y. Himeda, Green Chem., 2009, 11, 2018-2022.

[15] A. Staubitz, A. P. M. Robertson, I. Manners, Chem. Rev., 2010, 110, 4079-4124.

[16] A. Guerriero, H. Bricout, K. Sordakis, M. Peruzzini, E. Monflier, F. Hapiot, G. Laurenczy, L. Gonsalvi, ACS Catal., 2014, 4, 3002-3012.

[17] M. Yurderi, A. Bulut, M. Zahmakiran, M. Kaya, Appl. Catal. B, 2014, 160-161, 514-524.

[18] P. Z. Li, A. Aijaz, Q. Xu, Angew. Chem. Int. Ed., 2012, 51, 6753-6756.

[19] M. Haruta, T. Kobayashi, H. Sano , N. Yamada, Chem. Lett., 1987, 405-408.

[20] M. Haruta, N. Yamada, T. Kobayashi, S. Iijima, J. Catal., 1989, 115, 301-309.

[21] J. Biener, M. M. Biener, R. J. Madix, C. M. Friend, ACS Catal., 2015, 5, 6263-6270.

[22] M. Maciejewski, P. Fabrizioli, J. D. Grunwaldt, O. Sven Becker, A. 


\section{Graphical Abstract}

Chin. J. Catal., 2016, 37: 1594-1599 doi: 10.1016/S1872-2067(16)62547-0

\section{Gold-containing metal nanoparticles for catalytic hydrogen generation from liquid chemical hydrides}

Xinchun Yang, Qiang Xu*

National Institute of Advanced Industrial Science and Technology (AIST),

Japan; Kobe University, Japan

Hydrogen is considered a clean, effective and renewable energy carrier for a sustainable future. Gold-containing metal nanoparticles can be used as efficient catalysts for CO-free hydrogen generation from liquid chemical hydrides.

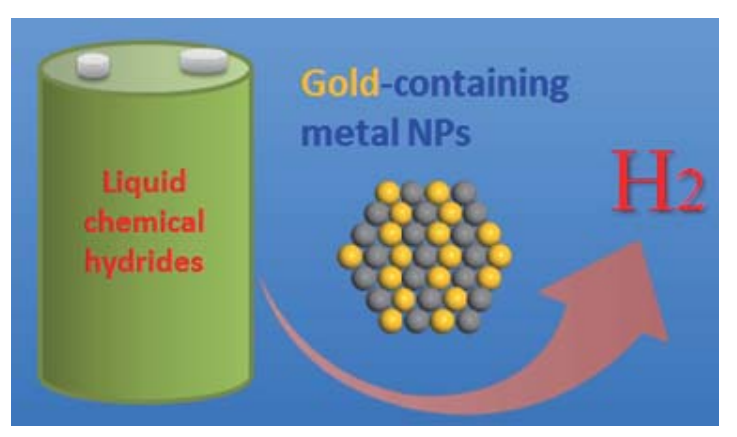

Baiker, Phys. Chem. Chem. Phys., 2001, 3, 3846-3855.

[23] A. Corma, H. Garcia, Chem. Soc. Rev., 2008, 37, 2096-2126.

[24] L. McEwan, M. Julius, S. Roberts, J. C. Q. Fletcher, Gold Bull., 43, 298-306.

[25] D. Pflasterer, A. S. K. Hashmi, Chem. Soc. Rev., 2016, 45, 1331-1367.

[26] E. C. Dreaden, A. M. Alkilany, X. Huang, C. J. Murphy, M. A. El-Sayed, Chem. Soc. Rev., 2012, 41, 2740-2779.

[27] J. Li, Q. L. Zhu, Q. Xu, Chimia, 2015, 69, 348-352.

[28] A. Boddien, D. Mellmann, F. Gärtner, R. Jackstell, H. Junge, P. J. Dyson, G. Laurenczy, R. Ludwig, M. Beller, Science, 2011, 333, 1733-1736.

[29] P. Sponholz, D. Mellmann, H. Junge, M. Beller, ChemSusChem., 2013, 6, 1172-1176.

[30] M. Grasemann, G. Laurenczy, Energy Environ. Sci., 2012, 5, 8171-8181.

[31] S. Fukuzumi, T. Kobayashi, T. Suenobu, J. Am. Chem. Soc., 2010, 132, 1496-1497.

[32] Z.-L. Wang, J. M. Yan, H. L. Wang, Y. Ping, Q. Jiang, J. Mater. Chem. A, 2013, 1, 12721-12725.

[33] M. Ojeda, E. Iglesia, Angew. Chem. Int. Ed., 2009, 121, 4894-4897.

[34] M. Yadav, T. Akita, N. Tsumori, Q. Xu, J. Mater. Chem., 2012, 22, 12582-12586.

[35] Q. Y. Bi, X. L. Du, Y. M. Liu, Y. Cao, H. Y. He, K. N. Fan, J. Am. Chem. Soc., 2012, 134, 8926-8933.

[36] Q. Q. Liu, X. F. Yang, Y. Q. Huang, S. T. Xu, X. L. Su, X. Pan, J. M. Xu, A. Q. Wang, C. H. Liang, X. K. Wang , T. Zhang, Energy Environ. Sci., 2015, 8, 3204-3207.

[37] X. C. Zhou, Y. J. Huang, W. Xing, C. P. Liu, J. H. Liao , T. H. Lu, Chem. Commun., 2008, 3540-3542.

[38] W. Y. Yu, G. M. Mullen, D. W. Flaherty , C. B. Mullins, J. Am. Chem. Soc., 2014, 136, 11070-11078.

[39] S. Wu, F. Yang, H. Wang, R. Chen, P. C. Sun , T. H. Chen, Chem. Commun., 2015, 51, 10887-10890.

[40] R. Li, J. H. Hu, M. S. Deng, H. L. Wang, X. J. Wang, Y. L. Hu, H. L. Jiang, J. Jiang, Q. Zhang, Y. Xie, Y. J. Xiong, Adv. Mater., 2014, 26, 4783-4788.

[41] L. J. Murray, M. Dinca, J. R. Long, Chem. Soc. Rev., 2009, 38, 1294-1314

[42] Y. B. Huang, M. Shen, X. S. Wang, P. C. Shi, H. F. Li, R. Cao, J. Catal., 2015, 330, 452-457.

[43] X. J. Gu, Z. H. Lu, H. L. Jiang, T. Akita, Q. Xu, J. Am. Chem. Soc., 2011, 133, 11822-11825.

[44] H. M. Dai, N. Cao, L. Yang, J. Su, W. Luo, G. Z. Cheng, J. Mater. Chem. A, 2014, 2, 11060-11064.

[45] H. M. Dai, B. Q. Xia, L. Wen, C. Du, J. Su, W. Luo, G. Z. Cheng, Appl.
Catal. B, 2015, 165, 57-62.

[46] F. Ke, L. H. Wang, J. F. Zhu, Nanoscale, 2015, 7, 8321-8325.

[47] S. Park, R. S. Ruoff, Nat. Nanotechnol., 2009, 4, 217-224.

[48] D. R. Dreyer, S. Park, C. W. Bielawski, R. S. Ruoff, Chem. Soc. Rev., 2010, 39, 228-240.

[49] Y. Chen, Q. L. Zhu, N. Tsumori, Q. Xu, J. Am. Chem. Soc., 2015, 137, 106-109.

[50] F.-Z. Song, Q.-L. Zhu, N. Tsumori, Q. Xu, ACS Catal., 2015, 5, 5141-5144.

[51] Z. L. Wang, J. M. Yan, Y. F. Zhang, Y. Ping, H. L. Wang, Q. Jiang, Nanoscale, 2014, 6, 3073-3077.

[52] J. M. Yan, Z. L. Wang, L. Gu, S. J. Li, H. L. Wang, W. T. Zheng, Q. Jiang, Adv. Energy Mater., 2015, 1500107.

[53] X. C. Yang, P. Pachfule, Y. Chen, N. Tsumori, Q. Xu, Chem. Commun., 2016, 52, 4171-4174.

[54] Z. L. Wang, J. M. Yan, Y. Ping, H. L. Wang, W. T. Zheng, Q. Jiang, Angew. Chem. Int. Ed., 2013, 52, 4406-4409.

[55] Y. J. Huang, X. C. Zhou, M. Yin, C. P. Liu, W. Xing, Chem. Mater., 2010, 22, 5122-5128.

[56] M. Zahmakiran, S. Özkar, Top. Catal., 2013, 56, 1171-1183.

[57] M. Chandra, Q. Xu, J. Power Sources, 2006, 156, 190-194.

[58] M. Chandra, Q. Xu, J. Power Sources, 2007, 168, 135-142.

[59] K. Aranishi, Q. L. Zhu, Q. Xu, ChemCatChem., 2014, 6, 1375-1379.

[60] W. Y. Chen, J. Ji, X. Feng, X. Z. Duan, G. Qian, P. Li, X. G. Zhou, D. Chen, W. K. Yuan, J. Am. Chem. Soc., 2014, 136, 16736-16739.

[61] K. Güngörmez, Ö. Metin, Appl. Catal. A, 2015, 494, 22-28.

[62] H. L. Jiang, Q. Xu, Catal. Today, 2011, 170, 56-63.

[63] H. Y. Liang, G. Z. Chen, S. Desinan, R. Rosei, F. Rosei, D. L. Ma, Int. J. Hydrogen Energy, 2012, 37, 17921-17927.

[64] A. Aijaz, A. Karkamkar, Y. J. Choi, N. Tsumori, E. Rönnebro, T. Autrey, H. Shioyama , Q. Xu, J. Am. Chem. Soc., 2012, 134, 13926-13929.

[65] J. F. Shen, L. Yang, K. Hu, W. Luo, G. Z. Cheng, Int. J. Hydrogen Energy, 2015, 40, 1062-1070.

[66] K. Kang, X. J. Gu, L. L. Guo, P. L. Liu, X. L. Sheng, Y. Y. Wu, J. Cheng, H. Q. Su, Int. J. Hydrogen Energy, 2015, 40, 12315-12324.

[67] H. L. Jiang, T. Umegaki, T. Akita, X. B. Zhang, M. Haruta, Q. Xu, Chem. Eur. J., 2010, 16, 3132-3137.

[68] Z. H. Lu, H.-L. Jiang, M. Yadav, K. Aranishi, Q. Xu, J. Mater. Chem., 2012, 22, 5065-5071.

[69] J. M. Yan, X. B. Zhang, T. Akita, M. Haruta, Q. Xu, J. Am. Chem. Soc., 2010, 132, 5326-5327.

[70] K. Aranishi, H. L. Jiang, T. Akita, M. Haruta, Q. Xu, Nano Res., 2011, 4, 1233-1241.

[71] J. W. Park, S. W. Lai, S. O. Cho, Int. J. Hydrogen Energy, 2015, 40, 16316-16322. 
[72] L. T. Guo, Y. Y. Cai, J. M. Ge, Y. N. Zhang, L. H. Gong, X. H. Li, K. X. Wang, Q. Z. Ren, J. Su, J. S. Chen, ACS Catal., 2015, 5, 388-392.
[73] Q. L. Zhu, J. Li, Q. Xu, J. Am. Chem. Soc., 2013, 135, 10210-10213.

[74] J. Li, Q. L. Zhu, Q. Xu, Chem. Commun., 2014, 50, 5899-5901.

\title{
含金金属纳米颗粒用于液相化学氢化物催化制氢
}

\author{
杨新春 ${ }^{\mathrm{a}, \mathrm{b}}$, 徐 强, ${ }^{\mathrm{a}, \mathrm{b}}$ * \\ a日本国立产业技术综合研究所, 大阪府池田市563-8577, 日本

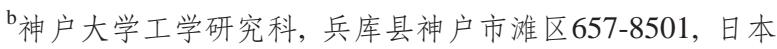

摘要: 液相化学氢化物以化学键的形式储存氢能, 被认为是一类很有前景的化学储氢材料. 液相化学氢化物的大规模应 用很大程度上依赖于高效催化系统的开发. 含金金属纳米颗粒在用于液相化学氢化物催化制氢中表现出优异的催化性能. 本文综述了金纳米颗粒和含金异金属纳米颗粒用于液相氢化物催化制氢的最新研究进展.

关键词: 金催化剂; 制氢; 甲酸; 氨硼烷; 多相催化

收稿日期: 2016-04-12. 接受日期: 2016-05-10. 出版日期: 2016-10-05.

*通讯联系人. 电话: +81-72-7519562; 传真: +81-72-7519628; 电子信箱: q.xu@aist.go.jp

本文的英文电子版由Elsevier出版社在ScienceDirect上出版(http://www.sciencedirect.com/science/journal/18722067). 